\title{
Professional Standards for School Principals in Turkey ${ }^{1}$
}

\begin{abstract}
İbrahim H. Karatas
Correspondence: İbrahim H. Karatas, Istanbul Medeniyet University, Faculty of Educational Sciences, Department of Educational Sciences, Division of Educational Administration, Supervision, Planning and Economics, North Campus, 34700, Üsküdar, İstanbul, Türkiye.
\end{abstract}

Received: January 18, 2016 Accepted: February 1, $2016 \quad$ Online Published: February 21, 2016

doi:10.11114/jets.v4i5.1310

URL: http://dx.doi.org/10.11114/jets.v4i5.1310

\begin{abstract}
This research aims to determine the professional standards required of in order to define the school administrative position in Turkey. It utilizes mixed methods research approach. Focus group interviews with 30 participants in three sessions with 10 participants from each group were conducted in three non-governmental organization schools based in Istanbul, Ankara, and Corum provinces in Turkey. Through the 7point Likert-type questionnaire -Professional Standards Scale for School Leaders (PSSSL) - was developed by the researcher and 328 members in NGOs founded by school heads and educational leaders in Turkey were sampled. The factor analysis of the scale with 0.994 internal consistency coefficient showed that $77.2 \%$ professional standards of school leadership was explained. According to research results, proficiency areas of school leaders determined were: (1) knowledge base, (2) effective communication, (3) institution management, (4) change leadership, (5) technology leadership, (6) educational leadership, (7) school-environment relations; and (8) life and society. The results of the current research will be useful for defining school leadership duty as a profession, obtaining professionally required personal employee rights, reorganizing school leader training programs, and relevant NGOs to be able to establish internal auditing mechanisms.
\end{abstract}

Keywords: professional proficiencies, professional standards, school administration

\section{Introduction}

A very rapid and multi-dimensional change process is deeply experienced in all walks of life. This change wave directly affects schools, education, thus, the context of school administration. According to Beck and Murphy (1993), a school administrator is viewed as value moderator, scientific manager, democratic leader, theory-oriented administrator, bureaucrat, facilitator, and educational leader. However, according to Murphy and Forsyth (1999), the 1990s were the reform period for school administration. These periods were described as post-industrial era which started in the 1980s. Therefore, new wave of change with increasing effectiveness brought about radical socio-economic, technological, cultural, and political transformations during these periods.

These social developments requiring school administration re-defined according to Murphy and Forsyth (1999) may be summarized as; changing production styles, social, and political dynamics, put in three headings. Hesapçığlu (2001) similarly argues that fundamental dynamics of change may be explained as information technology, postmodernism, and post-Fordist production approach. On the other hand, approaches forming the theoretical basics of educational administration also change (Bates, 2001; Beycioğlu and Dönmez, 2006). Within the educational administration field previously based on traditionalist, rationalist, and positivist approaches, the interpretive, critical, cognitive, symbolist, and cultural theories, respectively called post-positivism after 1970s, had been observed to have attracted attention. Theories affecting the field since 1990s up to this day have been post-modern thinking and its extensions like interpretive approach (Örücü and Şimşek, 2011; Turan, 2004).

Balc1 (2011) argue that the change and transformation experienced in social life and theoretical approaches influenced the context of school administration. School principals are under the influence of forces such as increasing accountability, student-centered leadership, collecting research data and making data-driven decisions, increasing competition and school choice, system-wide social integration, globalization, the concept of knowledge society, etc.

\footnotetext{
${ }^{1}$ The current research has been supported by TUBITAK BIDEB, within Post Doctorate Research Scholarship for
} Abroad 2219. 
"These forces require education and the school principals of such knowledge, skills, and understanding that have never been considered possible - maybe necessary- so far. This type of leadership requires the school principals to have analytic skills, cope with increasing competition and school choice concepts, and to achieve system-wide school integration/involvement" (Balc1, 2011:196). National Association of Elementary School Principals (NAESP), states in its report that being a school principal goes beyond the administration of a school in its traditional approach. The report adds that social and educational contexts need to be considered within school administration, and as a result, school principals need to have multi-dimensional competences and skills other than traditional proficiencies (NAESP, 2008, p. 2).

\subsection{School Principal Profession}

Quality and success of educational services are explained with achievement at school and in the classroom. Almost all relevant studies indicate that management success by the school administrators is significantly effective on students' achievement (Botha, 2006; Balyer and Gündüz, 2013; Robinson, Lloyd and Rowe, 2008). The rate of this school effect goes up to $78 \%$ in some studies (Marzano, Waters and McNulty, 2005).

School administrators are primarily responsible for all operations in school (Ministry of National Education [MONE], 2012). Therefore, school principals are required to be educators for schools and educational institutions, as well as to have administrative knowledge and skills to manage staff, business, finance, and relations needed by all other organizations. In this respect, school administration is an inter-disciplinary duty requiring competences in education and administration (Beatriz, Deborah, Hunter and Hopkins, 2008; Mestry and Singh, 2007; Turan and Şişman, 2000).

In other respects, the global and multi-dimensional wave of change opens educational paradigms for critique (Balc1, 2011; Bates, 2001; Beycioğlu and Dönmez, 2006; Fırat, 2006; Şimşek, 1997; Turan, 2004); and new needs require new educational processes (Balc1, 2011; Şimşek 2004; Turan and Şişman, 2000). Developing technology radically unsettles learning and teaching methods (Murphy and Forsyth, 1999) and reflection of all this wave of change on educational services depends on school principals' skills in change perception, conveying it to the institution, and administration.

The knowledge, skills, and practice competences of school principals who are required to meet above-stated needs have been discussed. School administration, considered a practical field rather than a theoretical field, is regarded as interdisciplinary. School administrators as qualified educational leaders are required to have sociologic, political, economic, cultural, and moral as well as pedagogical competences (Balc1, 2011; Gümüşeli, 2001; Turan and Şişman, 2000).

\subsection{Professional Standards for School Administration in Various Countries}

Consensus regarding school administration as a profession around the world is being formed. The standards for qualification levels of persons to undertake school principalship in the US in 1996 were defined (Interstate School Leaders Licensure Consortium [ISLLC], 1996; 2008; Louden and Wildy, 1999; Murphy, 2001). Countries such as Britain (Bush, 1998), Canada, Australia (Australian Institute for Teaching and School Leadership [AITSL], 2011), and New Zealand defines the qualities and standards for school administrators; and require such standards for school principals (Hallinger, 2003; Li and Liu, 2007).

South Africa is one of the countries which have been putting efforts to determine standards, in order to consider school principalship as a professional occupation (Van der Westhuizen and Van Vuuren, 2007). In 2007, as a result of continuing efforts since 1994, South Africa Department of Education determined six competency areas that school principals must possess as, "National Qualification for School Leadership [NQSL]" (Moloi, 2007; Bush, Kiggundu, Moorosi, 2011). With the will of South Africa Department of Education (DoE), two year principal qualification programmes were opened at universities to equip the incumbent and aspiring principals with these qualifications under the name of Advanced Certificate in School Leadership (ACE). Although these competencies are not compulsorily assigned to principalship yet, pilot applications conducted between 2007-2009 revealed that the principals are more equipped in issues of knowledge base, values, beliefs; and skills and they are more successful in school leadership as a result of the programs held (Bush, Joubert, Kiggundu and Van Rooyen, 2010; Mestry and Singh, 2007).

In addition, Organization for Economic Co-operation and Development (OECD) has held many meetings and published many reports in recent years, in order to improve school administrators' capacities in member countries (Beatriz, Deborah, Hunter and Hopkins, 2008; Darling-Hammond, LaPointe, Meyerson and Orr, 2007). As a result of a ten-) research, conducted by OECD, including 25 countries, 21 st century school administration was stated to be a system leadership and elements of the system were defined in eleven areas on four levels. These areas are: moral purpose on the 1 st level, staff development and strategic intelligence on the 2nd level; managing learning and teaching, improving the organization, and improving persons on the 3rd level; collaboration with a low-achieving school, leadership for educational improvement collaboration, community leadership, developing a school in difficult contexts; and work as 
change agent (Pont, Nusche and Hopkins, 2008: 33).

These standards defined for school administrators are based on various areas of service that school administrators take on. These areas are observed to be (1) change management, (2) educational and instructional leadership, (3) organizational administration, (4) personal and professional development, (5) team work (6) relationships with the community, and (7) ethics. In addition, belief, value, practical principles, knowledge base, and skills required by each area are listed. Figure 1 shows the emerging model of system leadership.

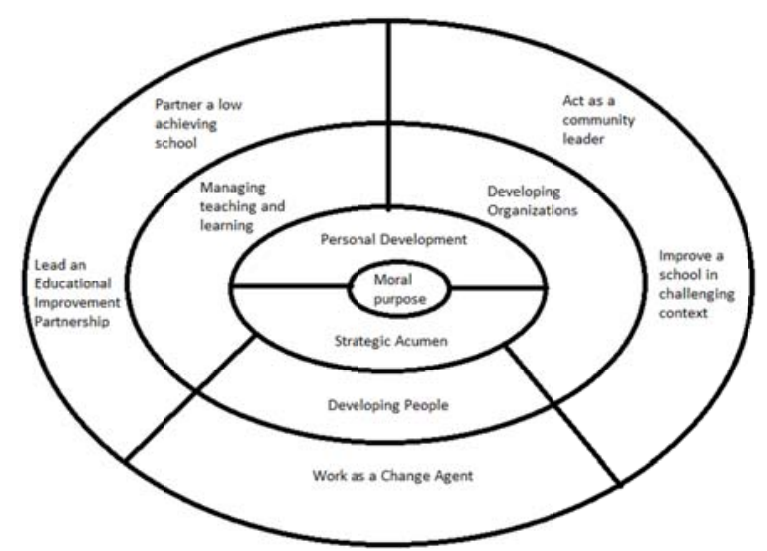

Figure 1. Emerging model of system leadership (Pont, Nusche and Hopkins, 2008).

\subsection{Efforts towards Defining Professional Standards for School Administration in Turkey}

Professional competences and proficiencies for school administrators in Turkey have attracted researchers' attention since 1970s. Bursalığlu (1976), Balcı (1981), Taymaz (1986), Aydın (1994); and Çelik (1995) conducted leading research in this field, and they were effective in shaping both undergraduate and graduate programs in educational administration and control, but legal recognition of school administration as a profession has not taken place, so far. Including educational administration and leadership in the 14th National Education Council's agenda in 1993 was a significant development. However, only three of the total 38 decisions made in the council were about educational administration and the decisions made were not satisfactorily executed (MONE, 1993).

Since mid-1990s, defining competence and proficiency areas for school administrators, providing a profession description, and their training have been among the topics that researchers in this field emphasized. Many scientific meetings have been held for this purpose and many studies have been published (Karataş and Şaşmaz, 2013). The first professional association of educational administration, on the other hand, was established in 1999. Also in 1999, school administrators were required through regulations to receive 120-hour training before service (MONE, 1999). However in 2004, regulations were amended and this requirement was removed. Within the framework of large-scale Improving School Leadership (Pont, Nusche and Moorman, 2008) research, a 10-year study conducted by OECD, involving 25 countries, a conference was hosted by MONE Foreign Affairs General Directorate. In that conference, competences that 21 st century school administration should feature, and what to do in order to make school administration an attractive profession were discussed (MONE], 2009).

School administration in Turkey is legally described as an additional service that should be undertaken by those who preferred teaching as a profession. In the first paragraph of article 43, describing teaching profession, of National Education Basic Law numbered 1739; teaching is described as a specialized professional undertaking - duties of teaching, instruction, and relevant administrative services. Therefore, school administration is not legally considered an independent profession.

Additionally, the definition of school administration and school administrators' responsibilities and authorities are included in operational regulations of relevant educational institution. According to the Regulations of Secondary Institutions (MONE, 2009) which was finalized with amendments made on 21 July 2012, basic responsibility of school administrators, described as educational and instructional leaders, are: (1) to be educational and instructional leader for teachers, students, parents, and the community, (2) taking measures towards increasing efficiency, building a team spirit, integrating the institution and the community, and improving organizational culture; and (3) keeping the school or the institution ready for service. While performing these basic duties, the school administration "continuously renews and improves the school or the institution through scientific and technology developments, efficiency and transparency principles. It uses time and all possibilities in order to achieve targets of the school or the institution" (MONE, 2009a). In order to achieve the above-mentioned, the school administration is required to (a) conduct research and planning, (b) to organize, (c) to guide, (d) to monitor, inspect, and evaluate; and (e) to undertake communication and coordination 
duties (MONE, 2009a).

When the 29-item list of school administrators' duties included in the said regulations is considered, it is seen that, beside the administration of education and instruction, school administrators are expected to do various management duties such as: facility management, monitoring, guidance and evaluation, staff management, organizational and professional development, budget management, technology management, and relations with the community (MONE, 2009a).

However, the definition and responsibilities included in the regulations and requirements are put forward when school administrators selected and appointed, do not match. According to Regulations on Appointment and Designation of School Administrators (MONE, 2009b), any candidate - a graduate of higher education - who has served as a teacher for three years and is presently employed in education and instruction may become an administrator as long as they pass the test offered by Ministery.

The content of the test done by Ministery to select the best school administrator candidates, is on the other hand, far from preparing the selected persons for the service. $60 \%$ of the examination is allocated for the effective regulations; $10 \%$ is about language skills, and another $10 \%$ involves official correspondence and protocol rules. Only $20 \%$ of the school administrators' examination test school administration, communication skills, human relations, school improvement, and educational and instructional ethics among knowledge, skills, and competences that a school administrator needs (MONE, 2009b).

It cannot be said that enough number of studies on school administration and qualifications of educational administrators in Turkey have been conducted (Bursalığlu, 1976; Balc1, 1981). Categorize of studies on professional competences of school administrators in last 20 years are grouped into five. The studies consisting of majority of research on school administrators' competences in the first group focused on school administrators' competences on some areas: knowledge management competences (Özsarıkamış, 2009), administrators' role and competences in controlling (Öncel, 2006), competences in the process of communicating with teachers (Öksüz, 1997), human relations competences (Okutan, 1988), competence levels of social skills (Çelik, 2004; Kara, 2000), competences of conflict management (Elma, 1998), competences in knowledge technology (Artul, 2004), and competences in change management (Ak, 2006; Gökçe, 2008). The second group includes studies on school administrators' general or specific management competences and the research focusing on revealing self-perceptions of teachers, students, inspectors, or school administrators (Dönmez, 2002). The third group involves studies focusing on questioning whether standards prepared by developed nations fit for Turkey (Arslan and Beytekin, 2004; Gümüsşeli, 2001; Töremen and Kolay, 2003; Turan and Şişman, 2000). This type of studies investigated the validity of standards defined in other countries as professional standards for school administration in Turkey. The fourth group of studies contributed school administrator standards developed particularly in Britain (Çınkır, 2002), the US (Gümüşeli, 2001), European Union countries (Erden and Erden, 2005) in general, or with a broader spectrum of samples in other countries into the local literature. The fifth group, on the other hand, consists of studies trying to define competences that school administrators in Turkey are required to have (Ağaoğlu, Gültekin ve Çubukçu, 2002; Aktul, 2004; Karadağ, 2011; Şahin, 2000).

When the professional proficiency areas that researchers defined for school administration are reviewed, it is observed that Şahin (2000) included knowledge and skill domains along with belief, value, and principles; whereas Ağaoğlu, Gültekin, and Çubukçu (2002) included only knowledge and skills. Karadağ's (2011) study, on the other hand, includes qualities that may be considered within belief, value, and principles categories. However, despite these studies, a national standards list for school administration has not been formed. Yet, awareness of the profession to be undertaken by the school administrator candidates can be raised through forming the definition and standards of the profession. It is expected that school administration would be defined as a profession, because a profession with a legal definition in the country would provide it with identity; thus, the profession would be rightfully valued and appreciated by the public.

The number of professional associations founded by school administrators has recently been increasing rapidly. Almost all professional organizations defines school administration as a profession, and its determined standards as their basic purposes (Karataş and Şaşmaz, 2013). However, no professional organization in Turkey has yet declared a comprehensive list of competences for school administrators. Ağaoğlu et al. (2012:172) state, "Evaluation of administrator's effectiveness and efficiency is significant in terms of balancing various pressure and power groups' on school and putting forward administrators' job description. Within this context, as basis for employing educational administrators' needs, common, comprehensive, consistent, and reliable list of competences should be built by institutions and organizations from all walks of life. Then they should be improved along with contemporary developments and national requirements. 
As summarized above, some developed countries defined standards, principles, and mission descriptions for school administrators. And also the research on professional competences and proficiencies in Turkey and relevant literature showed school administration needs to possess a five-dimensional whole of competences and proficiencies (Bayraktar, 2002). These are beliefs, values, principles, knowledge base, and skill areas (Turan and Şişman, 2000). Beliefs include basic global acknowledgements on which school administrators' opinions, views, attitudes, decisions, and actions are based; values feature basics of their value-oriented model personalities being reference to administrators' decisions and actions; and principles of practice. On the other hand, it involves application of principles as basis for professional performance and part of school culture. Knowledge base covers the knowledge base required by the school administration duty and that skill area is about school administrators' practical proficiency. Therefore, belief, value, and principles make up the proficiencies that school administrators are required to have; and they refer to the dimension associated with attitudes, belief, and perceptions. Skill and knowledge on the other hand, form the competencies that school administrators are required to feature and they mostly refer to the technical qualities required by the position.

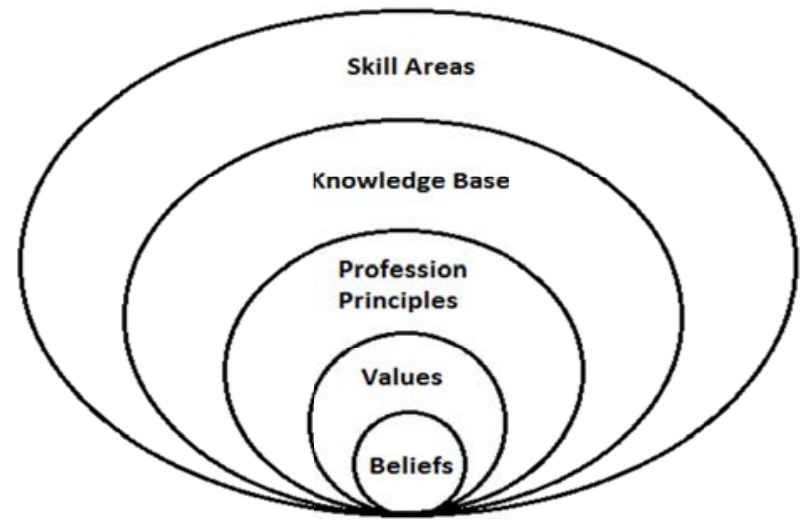

Figure 2. Proficiency and competence areas for school administrators

\subsection{The Purpose and Significance of the Study}

The current research aims to determine the knowledge base and the skill areas, namely the professional standards required by the mission, in order for the school administration to be recognized as a profession. Thus, the special qualities required by school administrator's job will have been revealed. For this purpose, a list of standards will be built in relation to views of school principals, teachers, parents, students, and NGOs established by school administrators, on what competences school administrators should possess.

Determining professional standards for school administrators will form the basis for understanding the type of responsibility and liability that the school administration has; the type of training the school administrators should receive; carrying out the appointment, evaluation, control, and transfer processes impartially; and determining needs of in-service training.

It must be admitted that determining professional standards for school administrators will play a definitive role in universities and other institutions adopting a standard for school administrator training programs. With the professional standards defined, it will be possible to review and reorganize, as per standards, the content, methods, and evaluation criteria in pre-service training for school administrators to-be; and in-service training for active school administrators.

On the other hand, defining the standards for school administrators will play a definitive role in services and efforts by professional organizations towards their members. With professional standards defined, school administrators' professional associations will have the opportunity to members' personal rights, processes of professional internal control, and professional development activities on sound fundamentals. Finally, defining school administrators' professional standards will guide the efforts for determining content in school administrator training programs, using relevant methods and techniques in programs, and self-improvement by faculty members. In addition, defining professional standards for school administration duty will help understand the difficulty level of the job and, thus, make demands of improving personal employee rights more consistent.

Ultimately, when non-governmental organizations recently established by educational and school administrators are rapidly increasing in numbers (Karataş and Şaşmaz, 2013), they take initiative more firmly in policy and regulations about the profession, this will enable them to contribute more in regulations. In addition, sustainability and wide use of activities developed, in order to support professional improvement and to control of colleagues' practice will increase.

\section{Method}


The current research utilizes sequential exploratory method which is a mix of qualitative and quantitative methods. Via sequential exploratory method, it is easier to explore a phenomenon and useful when developing and testing a new instrument (Creswell, 2003). In addition, rules defined by Davis (2007) to be taken into account when writing professional ethics principles were paid attention to.

\subsection{Study Group}

In the first phase, focus group interviews were held with 30 participants in three separate professional organizations established by educational and school administrators in İstanbul, Ankara and Çorum provinces. Ten participants including, principals, assistant principals, inspectors, academicians, and teachers participated in the focus groups. In order to improve representativeness of the study group, participators' gender, seniority, and branch distribution was planned to be balanced.

The second phase of the research included the application of Professional Standards Scale for School Leaders (PSSSL) which was based on findings from focus group studies and within relevant literature to school administrators, educational administrators, inspectors, teachers; and members of seven non-governmental organizations founded by academicians conducting research in the field of educational administration and control. The population of the study consisted of members of seven NGOs founded by educational administrators, school administrators, and teachers based in Istanbul, Ankara, Gaziantep, Çorum, Konya, Aksaray, and Afyon provinces in Turkey. Total number of members in the NGOs which were sent the scale was defined as 3336, based on information obtained on their websites and from their authorities.

\subsection{Data Collection Tools}

In the qualitative part of the current research, questions and forms prepared by the researcher based on relevant literature was used. The question "What are the professional competences that school administrators need to have?" was defined as a discussion starter to be orally asked to participants in the focus group interviews. Professional Competences Determination Form for School Administrators was built, in order for each participant to make their own list of professional competences. In addition, the researcher prepared guidebooks about how to conduct the study to be given to all study group participants and a seminar explaining how the study group worked.

In the quantitative part of the research, Professional Standards Scale for School Leaders (PSSSL) prepared by the researcher from results of focus group studies, was used. The scale consists of 8 factors and 98 items such as; knowledge base (16 items), organizational management (18 items), effective communication (11 items), technology leadership (13 items), change leadership (12 items), educational leadership (11 items), school-community relationships (10 items), and society and life (7 items). Demographic details of five items (gender, age, position, institution, and city) were added in the scale. The application time for the scale varies between 30 and 35 minutes.

\subsection{Data Collection}

Forms prepared by the researcher were used to collect data in focus group study. The researcher prepared guidebooks to describe how the research would be conducted and distributed these to all participants. In addition, the focus group's way of functioning was explained to all focus group members through a seminar. The participants were requested to respond to: "What are the professional competences that school administrators need to have?" Focus groups had 90-minute meetings with the moderator for three times each and discussed the professional competences defined. At the end of third meeting, each participant made up their own list of professional competences on Professional Competences Determination Form for School Administrators prepared by the researcher.

The PSSSL scale was sent to all members of each relevant NGOs through their administrators in December 2012 via email and members were asked to fill out the scale electronically. A total of 483 participants filled out the scale; however, 155 of these were filled incorrectly, so only 328 of these were subjected to statistical analysis.

\subsection{Process}

Data obtained from focus group studies were obtained through content analysis, the most suitable method (Kitzinger and Farquhar, 1999) for such research. Participants in the focus group studies listed and explained the professional competences required for school administration. These statements and explanations were scanned to define particularly repeating professional competences. After defining repeating professional competences, professional competences being similar, but not expressed with the same statements were categorized based on explanations. Following the categorization, defined professional competences were put in order from those with the highest frequency to those with the lowest frequencies.

Finally, the defined professional competences were thematically categorized. At this phase, in order to provide the research with internal validity, professional standards defined for school administrators in the US (Gümüşeli, 2001) and 
Britain (Çınkır, 2002), professional proficiency lists formed for school/educational administrators (Balc1, 1981; Şahin, 2000, Ağaoğlu, Altınkurt, Yılmaz and Karaköse, 2012) and competence categorization in Turkey were taken into account. Upon categorization of participant-suggested proficiency areas in different thematic categories of areas, consistency was provided by checking inter-relation among themes and their relations with others.

\subsection{Validity and Reliability}

In order to provide the internal reliability of analysis of data obtained through focus group studies, a second researcher, a field expert, was requested to categorize the collected data in themes and check the agreement of the defined themes. The rate of agreement between the themes defined by the second researcher and the previously defined themes was calculated as $84 \%$ with reliability=[agreement / (agreement + disagreement)] x 100 formulae and themes were found to be reliable (Büyüköztürk, Kılıç-Çakmak, Egün, Karadeniz and Demirel, 2008). In order to provide the research external reliability, the process was defined in details and obtained data and coding were archived by the researcher.

Exploratory factor analysis was used in the quantitative part of the research in order to investigate the factor structure made up of scores from obtained data through the scale. Thus, the construct validity of the scale was calculated. Cronbach's alpha internal consistency coefficient was checked in order to provide scale reliability.

\section{Results}

Data obtained in the current research, aiming to define professional competences for school administrators are presented below in two phases. The first phase includes findings obtained at the focus group studies and the second phase includes findings obtained through the scale.

\subsection{Results Obtained at the Focus Group Studies}

At the focus group interviews held with total 30 participants comprised of three separate groups of 10 in three separate professional organizations established by educational and school administrators, 52 competences that school administrators are required to have were stated. These competences were gathered under 7 professional proficiency areas. These proficiency areas are (1) change leadership, (2) effective communication, (3) organizational management, (4) technology leadership, (5) partner relations, (6) educational leadership, and (7) society and life, as presented in Table 1 .

Table 1. Proficiency Areas and Numbers Obtained in Focus Group Studies

\begin{tabular}{llll}
\hline & Proficiency Area & F & \% \\
\hline 1 & Organizational management & 112 & 33,2 \\
2 & Effective communication & 45 & 13,4 \\
3 & Instructional leadership & 40 & 11,9 \\
4 & School-community relations & 30 & 8,9 \\
5 & Change leadership & 25 & 7,4 \\
6 & Technology leadership & 20 & 5,9 \\
7 & Society and life & 18 & 5,3 \\
& Other & 47 & 13,9 \\
\hline & Total & 337 & 100 \\
\hline
\end{tabular}

Competencies within seven defined proficiency areas were categorized for the second time on knowledge base and skill areas. The second categorization was based on Turan and Sisman's (2000) definition of knowledge base and skill area that school administrators were required to have.

\subsection{Findings Associated with Reliability of Professional Standards Scale for School Leaders}

In the quantitative part of the research, the construct validity of the scale was checked through factor analysis. Analysis results showed that factor structure of the scale was valid. The reliability of the factors in the scale was checked through Cronbach's alpha coefficient. Alpha values found for factors varied between 0.960 and .977 whereas alpha values for the whole scale was 0.994 . Eight factors explain $77.2 \%$ of the total variance. Variance amounts that factors explained were respectively as follows: 14.09 for the first factor; 12.45 for the second factor; 11.79 for the third factor; 11.34 for the fourth factor; 11.24 for the fifth factor; 7.45 for the sixth factor; 5.72 for the seventh factor; and 4.86 for the eight factors. The lowest eigenvalue for the factors was calculated as 1.08. Factor analysis results are presented in Table 2 . 
Table 2. PSSSL exploratory factor analysis results and Chronbach's Alpha values

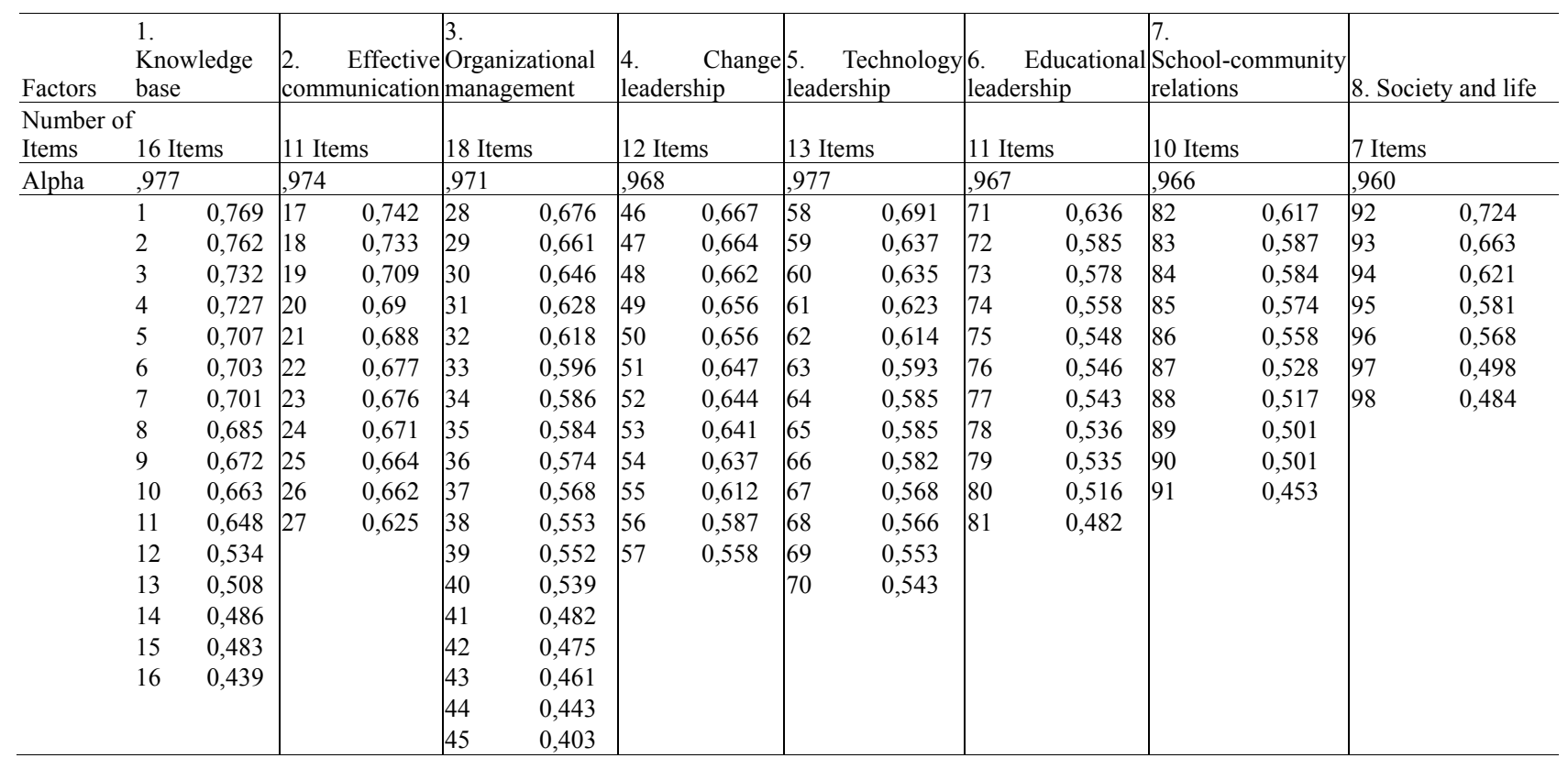

Correlation between the Chronbach's alpha internal consistency and factor scores was investigated in order to define the reliability of whole 98-item PSSSL with eight factors. Upon investigation, Chronbach's alpha internal consistency coefficient was calculated as 0.994 . Correlation between the Chronbach's alpha internal consistency and factor scores are presented in Table 3.

Table 3. Average scores of PSSSL factors and their standard deviations with correlation values between factors

\begin{tabular}{|c|c|c|c|c|c|c|c|c|c|c|}
\hline Factors & Average & $\begin{array}{l}\text { Standard } \\
\text { deviation }\end{array}$ & $\begin{array}{l}1 . \\
\text { Knowledge } \\
\text { base }\end{array}$ & $\begin{array}{l}\text { 2. Effective } \\
\text { communication }\end{array}$ & $\begin{array}{l}3 . \\
\text { Organizational } \\
\text { management }\end{array}$ & $\begin{array}{l}\text { 4. Change } \\
\text { leadership }\end{array}$ & $\begin{array}{l}5 . \\
\text { Technology } \\
\text { leadership }\end{array}$ & $\begin{array}{l}6 . \\
\text { Educational } \\
\text { leadership }\end{array}$ & $\begin{array}{l}7 . \\
\text { School-community } \\
\text { relations }\end{array}$ & $\begin{array}{l}8 . \\
\text { Society } \\
\text { and life }\end{array}$ \\
\hline 1. Knowledge base & 95,18 & 18,64 & - & & & & & & & \\
\hline $\begin{array}{l}\text { 2. Effective } \\
\text { communication }\end{array}$ & 67,97 & 12,66 & 0,73 & - & & & & & & \\
\hline $\begin{array}{l}\text { 3. Organizational } \\
\text { management } \\
\text { 4. Change }\end{array}$ & 109,56 & 18,86 & 0,82 & 0,80 & - & & & & & \\
\hline $\begin{array}{l}\text { leadership } \\
\text { 5. Technology }\end{array}$ & 73,66 & 12,70 & 0,85 & 0,71 & 0,78 & - & & & & \\
\hline $\begin{array}{l}\text { leadership } \\
\text { 6. Educational }\end{array}$ & 78,09 & 15,52 & 0,79 & 0,83 & 0,84 & 0,78 & - & & & \\
\hline $\begin{array}{l}\text { leadership } \\
7 .\end{array}$ & 65,77 & 13,56 & 0,86 & 0,76 & 0,85 & 0,84 & 0,78 & - & & \\
\hline $\begin{array}{l}\text { School-community } \\
\text { relations }\end{array}$ & 60,09 & 11,61 & 0,81 & 0,78 & 0,87 & 0.80 & 082 & 0.82 & - & \\
\hline 8. Society and Life & 40,94 & 8,62 & 0,71 & 0,82 & 0,79 & 0,69 & 0,83 & 0,71 & 0,77 & - \\
\hline Total & 591,26 & 101,99 & 0,92 & 0,88 & 0,94 & 0,89 & 0,92 & 0,92 & 0,92 & 0,86 \\
\hline
\end{tabular}

3.3 Findings Associated with Study of Professional Standards for School Leaders in relation to Variables of Gender, Age, Organization, Position, and City

Some analyses were conducted in order to find out whether professional standards defined for school administrators differed on independent variables. t-test was conducted to find if there was a significant difference in relation to gender and one-way variance analysis was conducted to find whether there was a significant difference on variables of age, position, organization, and city. The t-test results showed that there was not a significant difference between male and female participants in relation to the total and factor scores. According to the results of one-way variance analysis, no significant difference was observed between total and factor scores on participants' age, position, city where they served; however, a significant difference was found on position. Thus, a significant difference on position was observed between effective communication $(\mathrm{p}=0.01)$ and educational leadership $(\mathrm{p}=0.01)$ scores. On the LSD multiple comparison test, conducted in order to define the source of difference, the difference was observed to be, on both factors, in favor of teachers and top administrators/academicians and school principals and assistant school principals and; among school principals and assistant school principals. 


\section{Discussion}

The following were concluded in the current research conducted, in order to define the professional standards required for school administration to be recognized as a profession: School administration requires total 98 professional competences under 8 proficiency areas. According to the research results, school administrators' proficiency areas were defined, respectively, as: (1) knowledge base (16 competences), (2) organizational management (18 competences), (3) effective communication (11 competences), (4) technology leadership (13 competences), (5) change leadership (12 competences), (6) educational leadership (11 competences), (7) school-community relations (10 competences), and (8) society and life (7 competences).

Competences falling under the proficiency area of knowledge base, the first professional standard defined for school administrators, consist of items referring to theories and approaches associated with school administrators' educational-instructional services as school's purpose of existence. This proficiency area shows that school administrators need to have a sound knowledge base, which is fundamental for school administrators' responsibilities and liabilities as educational leaders (Turan and Sisman, 2000). In addition, this conclusion confirms the suitability of method of choosing school administrators from among candidates coming from teaching profession.

It was observed that the second proficiency area for school administrators was effective communication. Within this proficiency area, the competence about "1 Knowing the role and importance of communication in individual and social life" had the highest degree of agreement. Considering many studies investigating school administrators' proficiencies that found school administrators' communication skills on mid or low levels (Elma, 1998, Okutan, 1988, and Öksüz, 1997), it may be said that school administrators are required to have effective communication skills with awareness of theoretical fundamentals.

The third proficiency area for school administrators is organizational management. This proficiency area, also referred to as school business, consists of 18 competences including basic management skills. According to the research results, participants stated the most important competence within organizational management proficiency area as "knowing about rules of correspondence and reporting". According to this conclusion, it may be said that school administration is perceived as a top-level bureaucratic position in Turkey. Memduhoğlu (2007) also found out that, school administrators in Turkey perceive their task quite bureaucratic.

The fourth proficiency area for school administrators is change leadership. Change leadership includes competences of being aware of and understanding the rapid and unforeseeable change in social, political, and economical life (Murphy and Forsyth, 1999) and being able to adapt this change in education (Ak, 2006; Gökçe, ,2008). On the other hand, the school is by nature an organization working to reach long-term and intangible targets. The participants referring, most frequently, to the competence about "defining concrete and realistic targets" show that a leadership skill combining a rapid change wave and a visionary leadership is one of the basic requirements of school administration.

The fifth proficiency area for school administrators was technology leadership. Technology leadership includes skills for using technology effectively in education, school administration, communication, professional development, and individual life. Defining technology leadership, a newer concept compared with other proficiency areas (Hacıfazlıoğlu, Karadeniz, and Dalgıç, 2011), as one of the basic proficiency areas for school administration also indicates that there is awareness about effective management of communication technologies that have rapidly become widespread and will be reshaping all educational processes through FATIH Project. Participants' agreement on "using technology as an effective communication tool" on the highest level shows that school administrators are required to make their communication skills more effective through technology.

The sixth proficiency area for school administrators is educational leadership. Educational leadership involves an area that includes skills to manage processes such as curriculum, learning-teaching methods, classroom management, guidance services, teacher monitoring and evaluation, educational environments, extra-curricular activities, and special education that are associated with education and instruction. The knowledge base, the first proficiency area for the school administration, promotes the theoretical basis for educational leadership. However, the basic difference between school administration and other administrations is revealed as educational leadership is defined as a separate proficiency area including the skills to apply the theoretical knowledge at school (Marzano, Waters and McNulty, 2005).

The seventh proficiency area for school administrators is school-community relations. School-community relations proficiency area involves competences such as school's communication with community, community contribution in the school and school's contribution in the community, forming the culture of collaboration and governance with community, parent involvement, and follow up with graduates. Participants' agreeing with the competence about "school recognizes the community and its partners" on the highest level supports the research findings indicating that school administrators do not have adequate awareness of community. On the other hand, participants' least agreement is on "school involves community in decision making processes". This result shows that participants were cautious about 
the school involving community in decision making (Çelik, 2004).

The eight and the last proficiency area for school administrators was society and life. Society and life proficiency area is about school administrators' closely following the local and global community where they live, within political, economic, social, and cultural contexts and the competences of analyzing the reflections of social dynamism on education and school. In addition to the traditional theories explaining the interaction between school and community (Tezcan, 2003), when the results of studies showing that contemporary school administration needs to be aware of social, economic, political change and development are reviewed, it may be said that the society and life proficiency area is one of the basic proficiency areas for school administration.

The current research resulted in different professional proficiencies for school administrators than those defined in other countries and Turkey. The knowledge base was for the first time defined as a proficiency area for school administrators in the current research. Although many countries such as USA, UK and South Africa mention about knowledge base in their national qualifications or standard lists, they have not define as a key competence area for school leadership (AITSL, 2011; Bush, 1998; ISLLC, 2008; Moloi, 2007).

Effective communication and technology leadership areas are not found among six professional standards in the US, Britain, South Africa and five in Australia. Unlike in the current research, it is observed that ethical leadership is included in the US studies, self-improvement, collaboration with others, and accountability are included in Britain, self-improvement and collaboration with others are included in Australia and assuring quality and securing accountability is included in South Africa (AITSL, 2011; Bush, 1998; ISLLC, 2008; Moloi, 2007).

It was observed that research and professional development and personal characteristics, among the eight proficiency areas included in Şahin's (2000) study aiming to define professional proficiencies for school administrators in Turkey, are not included in the current research whereas human resources management and student affairs and school business competences were stated under organizational management proficiency area. It is seen that technology leadership and effective communication areas were not included among the professional proficiencies that Şahin defined. It is observed that serving the profession proficiency area, among the five proficiency areas that Ağaoğlu, Gültekin, and Çubukçu (2002) defined, is not contained within the current research. Technology leadership, school-community relations, and society and life proficiency areas, defined in the current research, are observed to be not included in the study that Ağaoğlu et al. conducted.

It may be said that one of the reasons for the difference between the current research and the studies conducted abroad and in Turkey stems from unified professional proficiencies lists including belief, value, performance, knowledge base, and skill areas under single lists. Belief, value, and practical principles were not included in the current research but only knowledge base and skill areas were defined. In addition, particularly studies in Turkey were conducted ten years ago and it may be said that technology leadership was not much of agenda those days. Finally, the proficiency area associated with society and life may be thought as a subject more talked of recently due to rapid social change and fast expansion in communication possibilities.

Professional proficiencies defined in the current research will become more meaningful with belief, value, and practical principles defined. Therefore, school administrator preparation programs can make up content based on proficiency and competences required by the school administration profession. In addition, effective use of these proficiencies to define school administration as a profession depends on adaptation, dissemination, and use of these proficiencies by school administrators' professional organizations in internal professional processes. Professional development processes may be reviewed and reorganized based on content and method upon revealing proficiencies of currently employed school administrators, in terms of these professional proficiencies, through large-scale and multi-leveled studies. Improvement and wide-spread use of these professional proficiencies will be facilitated via feedback obtained from novel research.

\section{References}

Ağaoğlu, E., Altınkurt Y., Yılmaz, K., \& Karaköse, T. (2012). Okul yöneticilerinin yeterliklerine ilişkin okul yöneticilerinin ve öğretmenlerin görüşleri (Kütahya İli). Education and Science, 37(164), 159-175.

Ağaoğlu, E., Gültekin, M., \& Çubukçu, Z. (2002). Okul yöneticisi yeterliklerine dayalı eğitim programı önerisi. In C. Elma ve Ş. Çınkır (eds), 21. Yüzyıl Eğitim Yöneticilerinin Yetiştirilmesi Sempozyumu Bildirileri (pp. 145-161). Ankara: Ankara Üniversitesi Eğitim Bilimleri Fakültesi Yayınları.

Ak, M. (2006). İlköğretim okulu yöneticilerinin değişimi yönetme yeterlikleri: Uşak ili örneği. Unpublished MS Thesis, Afyon Kocatepe Üniversitesi Sosyal Bilimler Enstitüsü, Afyon.

Arslan, H., \& Beytekin, F. (2004). Illköğretim okul müdürleri için okul liderliği standartlarının araştırllması. Paper preresented at the XIII. Ulusal Eğitim Bilimleri Kurultayı. İnönü Üniversitesi, Eğitim Fakültesi, Malatya.

Artul, S. İ. (2004). Etkili İlköğretim Okulu Yöneticisi Yeterlikleri: Adapazarı Örneği. Unpublished MS Thesis, Sakarya 
Üniversitesi Sosyal Bilimler Enstitüsü, Sakarya.

Australian Institute for Teaching and School Leadership [AITSL] 2011. Australian professional standards for principals. Retrieved from

http://www.aitsl.edu.au/verve/_resources/Australian_Professional_Standards_for_Principals.pdf

Aydın, M (1998). Ĕgitim yönetimi. Ankara: Hatipoğlu Yayıncılık.

Balcı, A. (1981). Lise yöneticisinin rolleri. Ä̈ Eğitim Bilimleri Fakültesi Dergisi, 14(1), 279-290.

Balc1, A. (2011). Eğitim yönetiminin değişen bağlamı ve eğitim yönetimi programlarına etkisi. Education and Sciences, 36(162), 196-208.

Balyer, A., \& Gündüz, Y. (2013). Öğretim lideri okul müdürlerinin öğrencilerin akademik başarısı üzerindeki etkisinin incelenmesi. Balıkesir Üniversitesi Sosyal Bilimler Enstitüsü Dergisi, 16(29), 107-129.

Bates, R. J. (2001). Eleştirel teori açısından eğitim yönetimi. Educational Administration: Theory and Practice, 7(4), 573-592.

Bayraktar, O. (2002). Yetkinliklere dayalı insan kaynakları yönetimi. Active (25), 30-44.

Beatriz, P., Deborah, N., Hunter, M., \& Hopkins, D. (2008). Improving school leadership, Volume 1: Policy and practice (Vol. 1). OECD publishing.

Beck, L. G., \& Murphy, J. (1993). Understanding the principalship: metaphorical themes, 1920's-1990's. New York: Teachers College Press.

Beycioğlu, K., \& Dönmez, B. (2006). Eğitim yönetiminde kuramsal bilginin üretimine ve uygulanmasına ilişkin bir değerlendirme. Educational Administration: Theory and Practice, 12(3), 317-342.

Botha, N. (2006). Leadership in school-based management: a case study in selected schools. South African Journal of Education, 26(3), 341-353.

Bursalığlu, Z. (1976). Eğitim yöneticisinin yeterlikleri: ilköğretmen okulu mrlerinin yeterliklerine ilişkin bir araştırma özeti. AÜ Ĕ̈itim Bilimleri Fakültesi Dergisi, 9(1), 321-324. http://dx.doi.org/10.1501/egifak_0000000452

Bush, T. (1998). The national professional qualification for headship: the key to effective school leadership. School Leadership and Management, 18 (3), 321-334. http://dx.doi.org/10.1080/13632439869529

Bush, T., Joubert, R., Kiggundu, E., \& Van Rooyen, J. (2010). Managing teaching and learning in South African schools. International Journal of Educational Development, 30(2), 162-168. http://dx.doi.org/10.1016/j.ijedudev.2009.04.008

Bush, T., Kiggundu, E., \& Moorosi, P. (2011). Preparing new principals in South Africa: the ACE: school leadership programme. South African Journal of Education, 31(1), 31-43.

Büyüköztürk, Ş., Kılıç-Çakmak, E., Akgün, Ö. E., Karadeniz, Ş., \& Demirel, F. (2008). Bilimsel araştırma yöntemleri. Ankara: Pegem Yayınları.

Çelik, H. (2004). İlköğretim okul yöneticilerinin sosyal beceri yeterlikleri. Unpublished MS Thesis, Abant İzzet Baysal Üniversitesi Sosyal Bilimler Enstitüsü, Bolu.

Çelik, V. (1995). Eğitim yöneticisinin vizyon ve misyonu. Educational Administration: Theory and Practice, 1(1), 47-53.

Çınkır, Ş. (2002). İngiltere'de okul müdürlerinin yetiştirilmesi: okul müdürleri için ulusal mesleki standartlar programı. In C. Elma ve Ş. Çınkır (Eds), 21. Yüzyıl Eğitim Yöneticilerinin Yetiştirilmesi Sempozyumu Bildirileri (pp. 293-304). Ankara: Ankara Üniversitesi Eğitim Bilimleri Fakültesi Yayınları.

Creswell, J. W. (2013). Research design: qualitative, quantitative, and mixed methods approaches. Sage publications.

Darling-Hammond, L., LaPointe, M., Meyerson, D., \& Orr, M. T. (2007). Preparing school leaders for a changing world: lessons from exemplary leadership development programs. School leadership study. Executive summary. Stanford Educational Leadership Institute. Retrieved from http://www.wallacefoundation.org/knowledge-center/school-leadership/key-research/Documents/Preparing-School -Leaders.pdf

Davis, M. (2007). Eighteen rules for writing a code of professional ethics. Science and Engineering Ethics, 13(2), 171-189. http://dx.doi.org/10.1007/s11948-007-9000-2

Dönmez, B. (2002). Müfettiş, okul müdürü ve öğretmen algılarına göre ilköğretim okulu müdürlerinin yeterlikleri. Educational Administration: Theory and Practice, 8(1), 27-45.

Elma, C. (1998). İlköğretim okulları yöneticilerinin çatışmayı yönetme yeterlikleri. Unpublished MS Thesis, Ankara Üniversitesi Sosyal Bilimler Enstitüsü, Ankara. 
Erden, A., \& Erden, H. (2005). Avrupa Birliği ülkelerinde okul yöneticileri. Milli Eğitim Dergisi, (167). Retrieved from http://dhgm.meb.gov.tr/yayimlar/dergiler/Milli_Egitim_Dergisi/167/index3-erden.htm

Fırat, N. Ş. (2006). Pozitivist yaklaşımın eğitim yönetimi alanına yansıması, alana getirdiği katkı ve sınırlılıklar. Dokuz Eylül Üniversitesi Buca Ë̆itim Fakültesi Dergisi, 20, 40-51.

Gökçe, F. (2008). Değişimin kavramsal modelleri ve değişim sürecinde eğitim yöneticilerinin yeterlikleri. Milli Eğitim, $172,237-252$.

Gümüşeli, A. İ. (2001). Çağdaş okul müdürünün liderlik alanları. Kuram ve Uygulamada Eğitim Yönetimi, 7(28), 531-348.

Hacıfazlıoğlu, Ö., Karadeniz, Ş., \& Dalgıç, G. (2011). Eğitim yöneticileri teknoloji liderliği öz-yeterlik ölçeğinin geçerlik ve güvenirlik çalışması. Kuram ve Uygulamada Eğitim Yönetimi, 17(2), 145-166.

Hallinger, P. (Ed.). (2003). Reshaping the landscape of school leadership development: A global perspective. Taylor and Francis.

Hesapçığlu, M. (2001). Postmodern toplumda eğitim, okul ve insan hakları. In O. Oğuz, A. Oktay, H. Ayhan (Eds), 21. Yüzyılda Eğitim ve Türk Eğitim Sistemi. İstanbul: Sedar Yayınc1lı.

Interstate School Leaders Licensure Consortium [ISLLC]. (1996). Standards for school leaders. Washington, DC: Council of Chief State School Officers. Retrieved from $\mathrm{http} / / /$ soe.unc.edu/academics/requirements/standards/ISLLC_Standards.pdf

Interstate School Leaders Licensure Consortium [ISLLC]. (2008). Standards for school leaders. Washington, DC: Council of Chief State School Officers. Retrieved from

http://www.ccsso.org/Resources/Publications/Educational_Leadership_Policy_Standards_ISLLC_2008_as_Adopte d_by_the_National_Policy_Board_for_Educational_Administration.html

Kara, S. (2000). Özel ilköğretim okulları müdürlerinin sosyal beceri yeterlik düzeyleri. Unpublished MS Thesis, Yıldız Teknik Üniversitesi Sosyal Bilimler Enstitüsü, İstanbul.

Karadağ, E. (2011). Okul müdürlerinin niteliklerine ilişkin olarak öğretmenlerin oluşturdukları bilişsel kurgular: fenomonolojik bir çözümleme. Education and Science, 36(159), 25-40.

Karataş, İ. H., \& Şaşmaz, Z. (2013). Okul ve eğitim yöneticilerinin kurmuş olduğu sivil toplum kuruluşlarının mesleki etkililiklerinin araştırılması: nitel bir analiz. Balıkesir Üniversitesi Sosyal Bilimler Enstitüsü Dergisi, 16(30), 23-44.

Kitzinger, J., \& Farquhar, C. (1999). The analytical potential of 'sensitive moments' in focus group discussions. In R. Barbour and J. Kitzinger (Eds), Developing Focus Group Research: Politics, Theory and Practice. (pp. 156-172). London: SAGE.

Li, J., \& Liu, Z. (2007). The comparison of the headmaster professional standards in America, the UK and New Zealand and its inspiration. Studies in Foreign Education, 12, 010.

Louden, W., \& Wildy, H. (1999). Short shrift to long lists: An alternative approach to the development of performance standards for school principals. Journal of Educational Administration,37(2), 99-121. http://dx.doi.org/10.1108/09578239910262944

Marzano, R. J., Waters, T., \& McNulty, B. A. (2005). School leadership that works: from research to results. Alexandria, VA: Association for Supervision and Curriculum Development.

Memduhoğlu, H. B. (2007). The issues of school management and training of school managers in turkish education system. Milli Eğitim Dergisi, 176, 86-97.

Mestry, R., \& Singh, P. (2007). Continuing professional development for principals: a South African perspective. South African Journal of Education, 27(3), 477-490.

Ministry of National Education [MONE]. (1993). XII. milli eğitim şurası kararları. Ankara MEB Talim Terbiye Kurulu Başkanlığı. Retrieved from http://ttkb.meb.gov.tr/meb_iys_dosyalar/2012_06/06021525_12_sura.pdf

Ministry of National Education [MONE]. (1999). Millî Eğitim Bakanlığı yönetici atama, değerlendirme, görevde yükselme ve yer değiştirme yönetmeliği. Tebliğler Dergisi, 2504.

Ministry of National Education [MONE]. (2009). Okul liderliğinin gelişstirilmesi konferansı özet raporu (09-10 Nisan 2009, Ankara). Ankara MEB Avrupa Birliği ve Dış İlişsiler Genel Müdürlüğü. Retrieved from http://abdigm.meb.gov.tr/eski/OLIG_ozet_rapor.html

Ministry of National Education [MONE]. (2009a). Ortaöğretim kurumları yönetmeliği. Resmi Gazete, 27305, 31 Temmuz 2009. 
Ministry of National Education [MONE]. (2009b). Millî Eğitim Bakanlığı eğitim kurumları yöneticilerinin atama ve yer değiştirmelerine ilişkin yönetmelik. Resmi Gazete, 27318, 13 Ağustos 2009.

Ministry of National Education [MONE]. (2012). Millî Eğitim Bakanlığı eğitim kurumları yöneticilerinin atama ve yer değiştirmelerine ilişkin yönetmelik. Resmi Gazete, 27318, 13 Ağustos 2009.

Moloi, K. (2007). An overview of education management in South Africa. South African Journal of Education, 27(3), 463-476.

Murphy, J. (2001). The changing face of leadership preparation. School Administrator, 58(10), 14-17.

Murphy, J., \& Forsyth, P. B. (1999). A decade of change: An overview. In J. Murphy, and P. B. Forsyth (Eds.) Educational administration: a decade of reform. (pp. 3-38). Thousand Oaks, CA: Corin Press.

National Association of Elementary School Principals [NAESP]. (2008). Leading learning communities: standards for what principals should know and be able to do. Alexandria, VA: Author. Retrieved from www.naesp.org/llc.pdf

Öksüz, C. (1997). İlköğretim okulları müdürlerinin öğretmenlerle iletişim sürecindeki yeterlikleri. Unpublished MS Thesis, Pamukkale Üniversitesi Sosyal Bilimler Enstitüsü, Denizli.

Okutan, M. (1988). Orta dereceli okul müdürlerinin insan ilişkileri yeterlikleri: Trabzon ili örneği. Unpublished MS Thesis, Hacettepe Üniversitesi Sosyal Bilimler Enstitüsü, Ankara.

Öncel, Y. (2006). İlköğretim okulu müdürlerinin denetimdeki rol ve yeterlikleri. Unpublished MS Thesis, Harran Üniversitesi Sosyal Bilimler Enstitüsü, Şanlıurfa.

Örücü, D., \& Şimşek, H. (2011). Akademisyenlerin gözünden Türkiye'de eğitim yönetiminin akademik durumu: nitel bir analiz. Educational Administration: Theory and Practice, 17(2), 167-197.

Özsarıkamış, S. (2009). İlköğretim okulu yöneticilerinin bilgi yönetimi yeterlikleri. Unpublished MS Thesis, Abant İzzet Baysal Üniversitesi Sosyal Bilimler Enstitüsü, Bolu.

Pont, B., Nusche, D., \& Hopkins, D. (Eds.). (2008). Improving school leadership, Volume 2: Case studies on system leadership. Organisation for Economic Co-operation and Development.

Robinson, V. M., Lloyd, C. A., \& Rowe, K. J. (2008). The impact of leadership on student outcomes: an analysis of the differential effects of leadership types. Educational administration quarterly, 44(5), 635-674. http://dx.doi.org/10.1177/0013161X08321509

Şahin, A. E. (2000). İlköğretim okulu müdürlerinin yeterlikleri. Educational Administration: Theory and Practice, 6(2), 243-260.

Şimşek, H. (1997). Pozitivizm ötesi paradigmatik dönüşüm ve eğitim yönetiminde kuram ve uygulamada yeni yaklaşımlar. Ĕ̈itim Yönetimi, 3(1), 97-109.

Şimşek, H. (2004). Eğitim yöneticilerinin yetiştirilmesi: karşılaştırmalı örnekler ve Türkiye için öneriler. Çağdaş Eğitim Dergisi., 29(307), 13-21.

Şişman, M., \& Turan, S. (2004). Dünyada eğitim ve yöneticilerinin yetiştirilmesine ilişkin başlıca yönelimler ve Türkiye için çıkarilabilecek bazı sonuçlar. Türk Eğitim Bilimleri Dergisi, 2(1), 13-26.

Taymaz, H. (1986). Okul yönetimi ve yönetici yetiştirme. Eğitim Bilimleri Fakültesi Dergisi, 19(1), 123-135.

Tezcan, M. (2003). Cumhuriyetimizin 80.yılında ülkemizde "eğitim sosyolojisi" alanının durumu ve sivil toplum örgütleri. Milli Eğitim Dergisi, 160. Retrieved from

http://dhgm.meb.gov.tr/yayimlar/dergiler/Milli_Egitim_Dergisi/160/tezcan.htm

Töremen, F., \& Kolay, Y. (2003). İlköğretim okulu yöneticilerinin sahip olması gereken yeterlikler. Milli Eğitim, 160. Retrieved from http://dhgm.meb.gov.tr/yayimlar/dergiler/Milli_Egitim_Dergisi/160/toremen-kolay.htm

Turan, S. (2004). Modernite ve postmodernite arasında bir insan bilimi olarak eğitim yönetimi. Akdeniz Üniversitesi Eğitim Fakültesi Dergisi, 1(1), 1-8.

Turan, S., \& Şişman, M. (2000). Okul yöneticileri için standartlar: eğitim yöneticilerinin bilgi temelleri üzerine düşünceler. Balıkesir Üniversitesi Sosyal Bilimler Enstitüsü Dergisi, 3(4), 68-87.

Van der Westhuizen, P., \& Van Vuuren, H. (2007). Professionalising principalship in South Africa. South African Journal of Education, 27(3), 431-446.

\section{(c)) EY}

This work is licensed under a Creative Commons Attribution 3.0 License. 